\title{
The profile of an intuitive \\ decision maker and the use of intuition in decision-making practice
}

\section{Introduction}

Intuition is a well-known concept. It can safely be said that everybody, to a greater or lesser extent, makes use of it in both personal and professional situations. It is most often experienced, in a conscious or unconscious way, in the decision-making process. The notion of intuition is widely described both in popular literature, where it is not supported by scientific evidence, as well as in specialist literature, mainly in the field of psychology (Markowski 2012, p. 26). It should be noted, however, that research into the concept of intuition is increasingly being undertaken in the area of management. This is due to the fact that modern managers are forced to act and make decisions in complex, sometimes even extreme, environments. It turns out that in such circumstances intuitive decisionmaking is rated by managers almost on a par with rational and analytical decision-making processes. In their work, managers often have to deal with situations that require creative,

Kamila Malewska, Ph.D. Poznań University of Economics and Business Theory of Organization and Management Department, non-stereotypical and innovative thinking. In addition, the time to make an appropriate decision is usually limited, which is when intuition plays a particularly important role as it triggers some not entirely conscious 
processes in the minds of decision makers. These processes help them relate the current situation to previously known situations from training, the literature, or personal experience (Serafin 2006, p. 113).

The literature on the subject suggests that an intuitive decision-maker differs from other types of decision makers. They possess a set of traits, skills and abilities that make up a specific personality profile. The question remains whether the possession of these characteristics and predispositions determines the degree of using intuition in the practice of decision-making.

The aim of this paper is to determine the relationship between the personality traits identified in the literature as characteristic of an intuitive decision-maker and the use of intuition in the decision-making process. In order to empirically verify this issue, the author conducted a pilot study.

The article consists of three principal parts and is both theoretical and empirical in nature. The first part presents the essence of intuition and attempts to define this ambiguous concept. Next, the personality traits, abilities and predispositions which make up the profile of an intuitive decision maker are discussed. The final part of the paper is devoted to presenting the results obtained in the course of this empirical research.

This study of relevant literature in the area of intuition was conducted within the research project "The impact of managerial intuitive potential on the effectiveness of decision making processes", financed by the National Science Centre, Poland (funds allocated on the basis of decision No. DEC-2014/13/D/ HS4/01750).

\section{The concept of intuition}

The concept of intuition is unique: and its colloquial understanding is significantly different from its scientific definition. This is due to the fact that intuition is often treated as a magical, mysterious ability to predict future events, being referred to as a "sixth sense" as well as a characteristic mainly of women. It should be emphasized, however, that attempts to clearly and reliably define this notion were first made by ancient philosophers. Their work is continued by, among others, contemporary psychologists and researchers in the field of management (Szerzyńska 2009, p. 133).

When defining intuition, most authors state that it is "the opposite of logical, rational thinking" (Haensel, Heuch, Schweitzer 2002). Colloquially, intuition is referred to as a gut feeling. It is a kind of inner conviction about something being right without any prior consideration or reflection.

Theory of Organization and Management 
Intuition is sometimes defined as an extraordinary state of mind, a state of knowledge experienced in unforeseen circumstances; it is the voice of the subconscious.

In the literature, many definitions of the term "intuition" can be found, and their dissimilarity results primarily from its irrational character. Other reasons for the differences in defining this concept include controversies regarding the determination of its constituent elements, the factors affecting it, its scope, characteristics, homogeneity, the mechanisms involved in its formation, its impact on the effectiveness of decision-making, as well as the existence of a relationship between intuition and the experience of the decision maker. Based on an analysis of the literature, it can be seen that intuition is presented from three perspectives (Stańczyk and Sus 2013, p. 6):

- as a process (Jung 1933; Westcott and Ranzoni 1963; Raidl and Lubart 2000),

- as an outcome (Kahneman 2003),

- as an attribute (Myers 2002; Policastro 1999).

Despite considerable differences in defining the concept of intuition, which primarily concern the issue of whether the intuitive process is conscious or subconscious, some of its common features can be identified that are accepted by most authors (Simon 1987; Agor 1998; Hogarth 2001; Klein 2003; Sadler-Smith 2008; Betsch 2008). These include the following:

- intuition is a thought process that occurs automatically,

- the process is based on knowledge structures formed as a result of various types of learning (its essence is the ability to apply previously acquired experience to current actions),

- it occurs, at least in part, unconsciously,

- its outcomes can include feelings, signals or interpretations.

For the purpose of this study, a definition was adopted which describes intuition as a thought process, the result of which is understanding, learning or acquiring knowledge without the participation of rational reasoning. Intuition is not a negation of logical thinking but it involves applying rules which are different from classical logical reasoning (Goldberg 2000, Rowan 1987). Intuition consists of fixed analyses transformed into a quick response habit. It is the result of many years of experience and training (Hogarth 2001). It should be emphasized that intuition does not occur independently of analysis. Both of these processes are important complementary elements of effective decisionmaking. Intuition makes it possible to synthesize many years of experience and learning, transforming them into difficult to substantiate rational knowledge (Tokarski 2001, p. 268). 


\section{Characteristics of an intuitive decision maker}

Researchers dealing with the issue of intuition postulate that an intuitive decision maker is characterized by specific traits, abilities and predispositions that distinguish them from other decision makers (Agor 1998; Harper 1998; Woiceshyn 2009). These include both positive and negative features, which are presented in table 1.

Table 1. Profile of an intuitive decision-maker

\begin{tabular}{|c|c|c|}
\hline \multicolumn{3}{|c|}{ Profile of an intuitive decision-maker } \\
\hline Feature & Description & $\begin{array}{l}\text { Posi- } \\
\text { tive/ } \\
\text { negative }\end{array}$ \\
\hline Concentration & $\begin{array}{l}\text { - intense concentration on the decision-making process, } \\
\text { - analysing and processing current data while constantly seeking } \\
\text { new information, } \\
\text { - emotional commitment to the decision-making process, } \\
\text { - seeking an optimal solution to the identified problem, }\end{array}$ & positive \\
\hline Motivation & $\begin{array}{l}\text { - internal motivation to seek answers to emerging questions as } \\
\text { well as solutions better than those of competitors, }\end{array}$ & positive \\
\hline Self-awareness & $\begin{array}{l}\text { - awareness of the individual stages of decision-making, } \\
\text { - conviction as to the rightness of the actions taken, }\end{array}$ & positive \\
\hline Innovativeness & $\begin{array}{l}\text { - generating unique solutions that are not extensions or } \\
\text { continuations of earlier proposals, }\end{array}$ & positive \\
\hline $\begin{array}{l}\text { The ability to } \\
\text { process and } \\
\text { filter informa- } \\
\text { tion }\end{array}$ & $\begin{array}{l}\text { - ability to process large amounts of information (in the case of } \\
\text { information noise) and identify and use that which is of key } \\
\text { relevance to a given decision, }\end{array}$ & positive \\
\hline Sense of timing & $\begin{array}{l}\text { - ability to synthesize the problem and the decision-making } \\
\text { situation and identify the right moment for action, }\end{array}$ & positive \\
\hline Creativity & $\begin{array}{l}\text { - ability to generate solutions to seemingly unsolvable problems, } \\
\text { - asking provocative but constructive questions, }\end{array}$ & positive \\
\hline $\begin{array}{l}\text { Mindfulness } \\
\text { (sensitivity to } \\
\text { stimuli coming } \\
\text { from the envi- } \\
\text { ronment) }\end{array}$ & $\begin{array}{l}\text { - ability to create, identify and seize opportunities emerging in } \\
\text { the environment, }\end{array}$ & positive \\
\hline
\end{tabular}




\begin{tabular}{l|l|l}
\hline Risk propensity & $\begin{array}{l}\text { - making decisions in conditions characterised by risk and } \\
\text { uncertainty (even without sufficient information), } \\
\text { remaining on decision-making standby, }\end{array}$ & $\begin{array}{l}\text { posi- } \\
\text { tive/ } \\
\text { negative }\end{array}$ \\
\hline Confidence & $\begin{array}{l}\text { - conviction as to the rightness of the decisions made, } \\
\text { problems with presenting solutions (rational arguments } \\
\text { supporting them) and implementing them in practice, }\end{array}$ & $\begin{array}{l}\text { posi- } \\
\text { tive/ } \\
\text { negative }\end{array}$ \\
\hline $\begin{array}{l}\text { Rashness (lack } \\
\text { of perseverance) }\end{array}$ & $\begin{array}{l}\text { - drawing conclusions too hastily, } \\
\text { overlooking facts, }\end{array}$ & negative \\
\hline $\begin{array}{l}\text { Becoming bored } \\
\text { easily }\end{array}$ & $\bullet$ aversion to routine activities and analysing details. & negative \\
\hline
\end{tabular}

Source: own compilation based on (Agor 1987, p. 163; Agor 1998, p. 277; Harper 1998, p. 145; Woiceshyn 2009, p. 311)

Summarizing the above list of the traits, abilities and predispositions of an intuitive decision-maker, it can be noticed that positive features predominate. In addition, it should be noted that these features correspond to the complex conditions under which modern enterprises operate, including dynamic changes occurring in the environment; excess or lack of information; the necessity to make decisions in conditions characterised by risk and uncertainty; time pressure; and intense competition. Such conditions mean that decisionmakers have to possess specific features that enable them to function efficiently and make effective decisions. These features include the ability to generate and identify opportunities that appear in the environment and create unique solutions, which guarantee the survival and development of the organization in a competitive market. The ability to analyse a large amount of information and extract that which is essential with regard to a given decision makes it possible to implement a decision-making process even in the case of information noise. On the other hand, risk propensity and a readiness to make decisions make for efficient functioning in conditions of risk and uncertainty. The ability to make quick decisions, which is characteristic of an intuitive decision-making process, as well as confidence and the conviction of the rightness of one's decisions are a response to time pressure, which is ubiquitous in today's business operations.

In view of the above, questions arise whether the features presented in the literature of an intuitive decision-maker translate into the use of intuition in decision-making practice; whether individuals possessing these features to a greater extent than other decision-makers apply intuition in their decision- 
making processes; and, finally, whether a relationship exists between selected elements of an intuitive decision-maker's profile and the use of intuition in decision-making.

\section{Research procedure and results}

The aim of the research was to identify the relationship between the personality traits defined in the literature as characteristic of an intuitive decision maker and the use of intuition in the practice of decision making.

The research had the form of a pilot study. It included 48 managers at all levels of one enterprise (the entire management of this company) operating in the food industry. The research was carried out using the questionnaire method, the questionnaire consisting of two parts: one designed to diagnose the level of personality traits typical of an intuitive decision maker, and the other one designed to determine the extent to which intuition was used in decisionmaking. In the first part, the respondents were asked to assess whether and to what degree they possessed 17 personality traits identified by the author (each rated on a scale from 1 to 5). The part diagnosing the extent to which intuition was used in decision-making practice consisted of 13 questions related to various aspects of the decision-making process (identifying problems; sources of data and information; methods of information processing; ways of analysing problems; methods of problem solving; evaluation of alternative options; attitude to risk and uncertainty; documentation of the decision-making process; stages in the decision-making process; commitment of the decision maker; presentation of the decision-making process and the decisions made; logical reasoning). Respondents were asked to choose one of two possible answers. For each of the questions, one of the answers indicated the use of an analytical (rational) approach, and the other pointed to an intuitive approach. This procedure made it possible to determine the dominant approach and, consequently, to identify more specific decision making styles (intuitive, quasi-intuitive, balanced, quasirational, and rational).

The form of the questions was similar to those used in a questionnaire evaluating the level of intuitive potential and the degree of using intuition developed by W.H. Agor (1998), though the content of the questions was by the author.

An analysis of the completed questionnaires reveals that the largest group of respondents (36\%) represented a balanced style of decision making, characterized by using the intuitive and analytical approaches in equal measure. In second

Theory of Organization and Management 


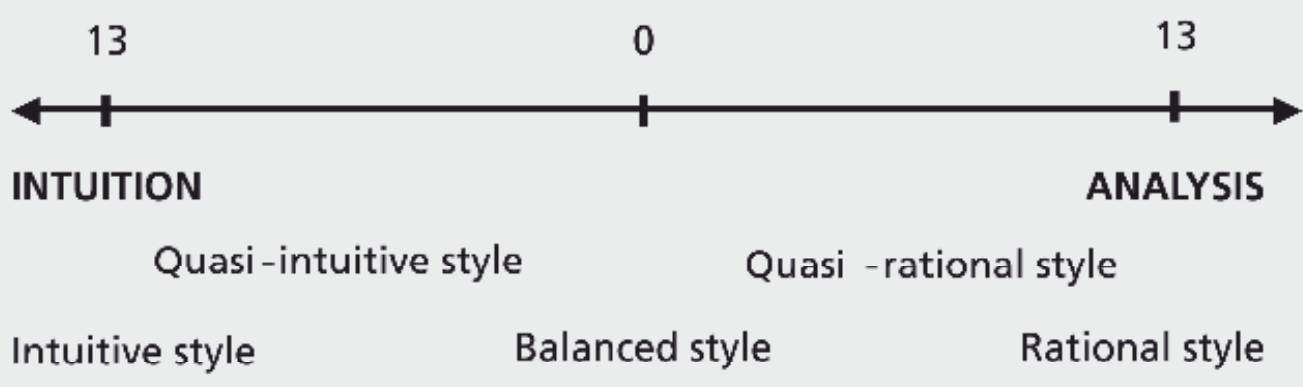

\section{Figure 1. Decision-making styles}

Source: own compilation based on (Allinson, Hayes 2003)

place were decision-makers representing the quasi-rational style $(28 \%)$ in which the analytical approach predominates over the intuitive. The third largest group comprised respondents making decisions in a quasi-intuitive way $(25 \%)$, where

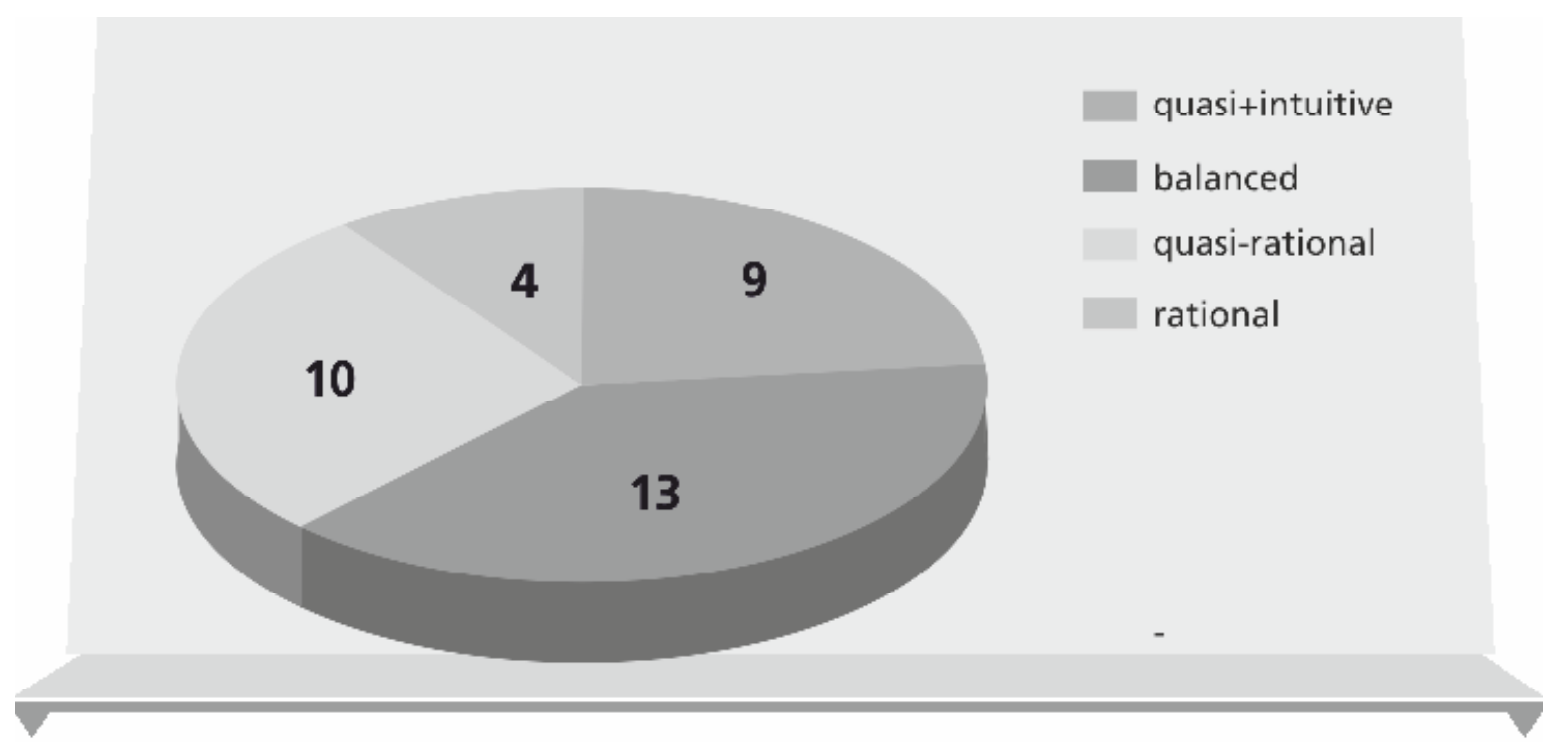

Figure 2: The proportions of respondents using specific decision-making styles

Source: own research 
the intuitive approach takes precedence over the analytical one. The fourth decision-making style identified among the respondents was the rational style. It is worth noting that none of the respondents represented the "pure" intuitive style. Summing up, it can be stated that the vast majority of respondents represented a style of decision-making which involved various combinations of the intuitive and analytical approaches (89\%).

Considering the results obtained through an analysis of the first part of the questionnaire, which focused on the respondents' self-assessment in terms of possessing specific personality traits, it should be noted that the total sum of the ratings obtained for all the assessed features that create the profile of an intuitive manager is the highest in the case of respondents representing the quasi-intuitive style. In the case of other approaches to making decisions (i.e. balanced, quasirational and rational), the numbers are lower. This means that the personality profile of an intuitive decision-maker that is typically presented in the literature to the greatest extent (in comparison with managers representing other approaches to decision-making), does in fact correspond to the features and predispositions characteristic of those who use intuitive management in practice.

In addition, it can be observed that although the total sum of the ratings for all the assessed features is the highest for managers using the quasi-intuitive approach, the respondents' assessments with regard to the intensity of individual personality traits are relatively similar (regardless of the decision-making style represented). Some differences can be noticed only in the case of the rational style. Managers representing this style of decision-making rated such personality traits as self-esteem, independence in making decisions, self-confidence and risk propensity decidedly lower than other respondents. On the other hand, they assigned higher ratings to such features as proactiveness and strong motivation to achieve goals, perseverance, enthusiasm and dedication to work, ambition, as well as team leadership. Another rating which also differs (negatively) from the others is the assessment of the feature defined as the ability to cope with failure (learning from mistakes) in the case of the balanced approach.

In order to identify the relationship between the respondents' specific personality traits and the use of intuition in decision-making, the Pearson linear correlation coefficient was used to determine the level of linear relationships between the random variables. The value of the correlation coefficient falls within the closed interval $[-1,1]$. The higher its absolute value is, the stronger the linear relationship between variables. A value of 0 means that there is no linear relationship between the variables; a value of 1 is interpreted as a positive relationship between the analysed variables; while a value of -1 indicates the

Theory of Organization and Management 
existence of a negative relationship between the examined features. In order to verify any potential regularities, one of the most popular and most frequently used statistical methods, analysis of variance (ANOVA), was also used.

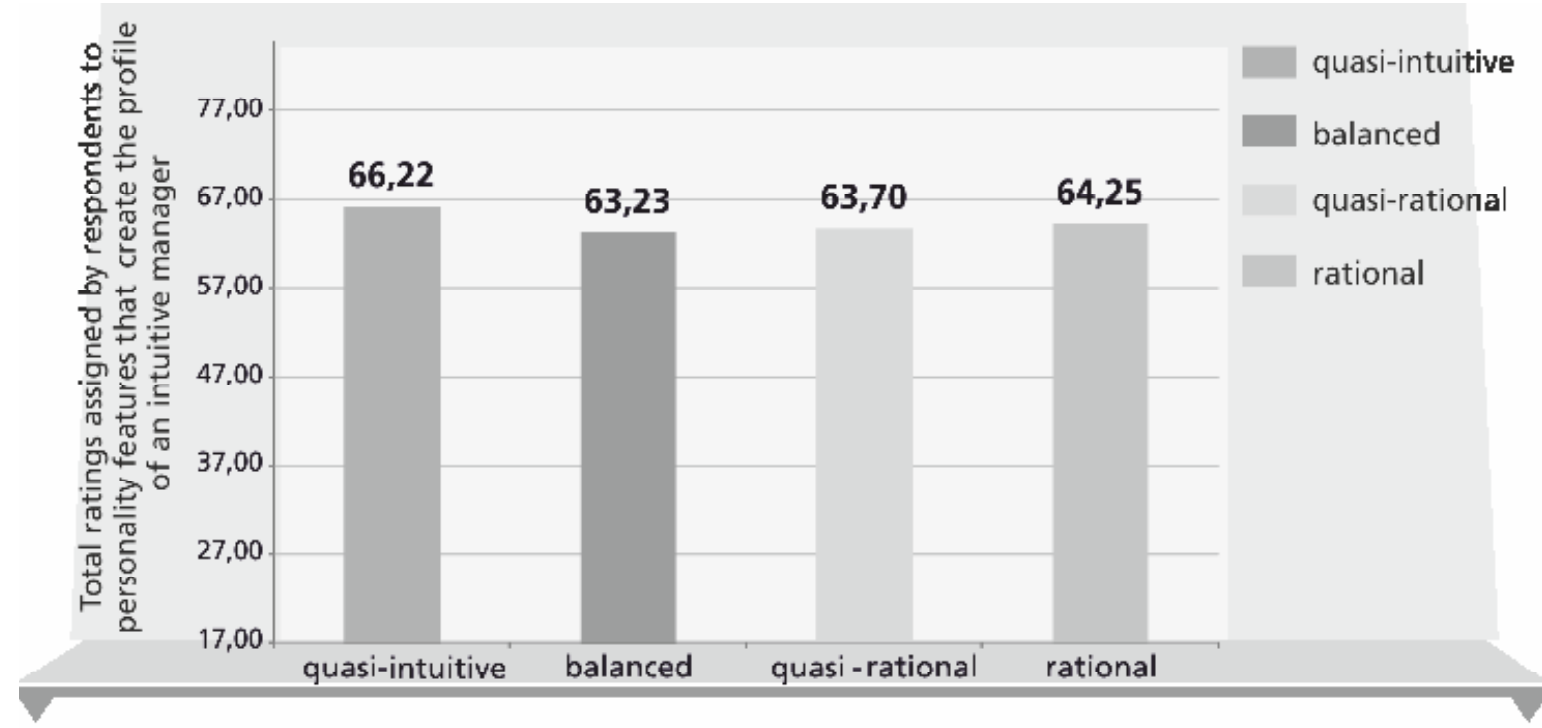

Figure 3. Total ratings assigned by respondents to personality features that create the profile of an intuitive manager according to decision-making styles

Source: own research

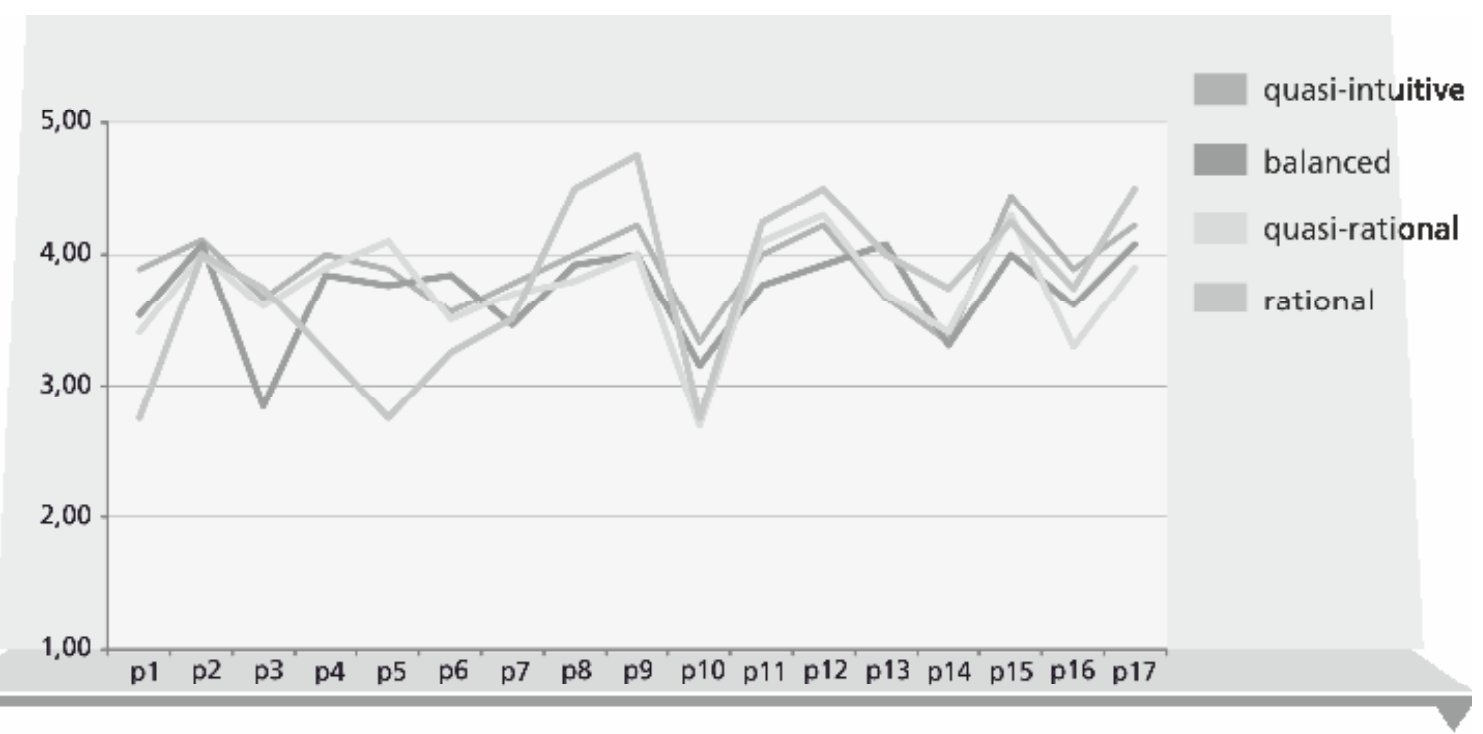

Figure 4. Average ratings related to possessing the personality traits of an intuitive decision maker (respondents' self-assessment)

Source: own research 


\section{Legend:}

\section{Personality traits of an intuitive decision maker}

p1 - self-esteem

p2 - willingness to learn

p3 - ability to cope with failure (learning from mistakes)

p4 - ability to identify and seize opportunities

p5 - independence in decision-making (decision readiness - the ability to make decisions in conditions of risk and uncertainty)

p6 - confidence

p7 - flexibility (the ability to adapt to changing environmental conditions)

p8 - proactiveness and strong motivation to achieve goals

p9 - perseverance
P10 - risk propensity

P11 - enthusiasm and dedication to work

p12 - ambition

p13 - ability to think strategically (futureoriented thinking)

p14 - team leadership

p15 - willingness to cooperate

p16 - creativity and innovativeness

p17 - need for achievement

The statistical analyses revealed weak relationships (correlation strength $0.2-$ 0.4 ) between employing the quasi-intuitive approach and personality traits such as self-esteem, independence in decision making (decision readiness - the ability to make decisions in conditions of risk and uncertainty), and risk propensity. The obtained results confirm opinions formulated in relation to the intuitive decision-maker. Only a self-confident person with a significant self-esteem is able to trust his experience and intuitive potential in decisions-making process (even in the absence of sufficient information). Besides, it is typical for an intuitive decision maker remaining on decision-making standby, which means the ability to make decisions when operating in conditions of risk and uncertainty. This is directly related to the risk propensity.

Linear relationships of a similar strength were also identified between using the rational approach and the assessment of the following characteristics: ambition (the decision maker demands a lot from themselves and others), and being team leader. These findings mean that the greater intensity of these two groups of characteristics (in respondents' opinions), the more rational style the decision maker represented. Although only the personality traits, abilities and predispositions postulated in the literature as typical for an intuitive decision-

Theory of Organization and Management 
maker, have been evaluated, it can be noted that selected ones have also proved adequate for a rational decision-maker. These features include ambition in action and the role of leader in the group. This means that certain features and abilities are common to both an intuitive and rational manager, while others clearly differentiate between these two extreme types of decision makers. These differentiating qualities can certainly include: self-esteem, decision-making willingness, risk-taking, innovative approach to solved problems and the ability to think creatively.

Correlations were also discovered between the ratings given to individual characteristics. The higher respondents rated the self-esteem trait, the higher they assessed their risk propensity. A similar relationship occurred between enthusiasm and dedication to work, and ambition.

\section{Conclusions}

Numerous factors, both internal and external, affect the manner of making decisions. These include such features as the personality traits, abilities and predispositions of the decision-maker (Laufer 2008; Kahneman, Klein 2009, pp. 515-525; Salas, Rosen, DiazGrandos 2010, pp. 941 -973; Blume, Covin 2011, p. 140). Extensive lists of attributes and skills characteristic of an intuitive decisionmaker can be found in the literature. The question arises whether possessing these features translates into the use of intuition in the practice of decision making. This pilot study, conducted on a small sample, proved the existence of a relationship between the use of the quasi-intuitive style in decision making and selected personality traits. The results obtained can be expressed in the form of the following preliminary conclusions:

1. A linear relationship exists between the use of the quasi-intuitive style and a higher assessment regarding the intensity of the following personality traits: self-esteem, decision readiness and risk propensity.

2. A linear relationship exists between the use of the quasi-rational and rational styles and the intensity of such features as ambition and team leadership.

3. A linear relationship exists between selected personality traits: such a relationship was identified between self-esteem and risk propensity, and between enthusiasm and dedication to work and ambition.

4. It seems desirable to conduct more extensive empirical research in order to more accurately determine the relationships between the personality traits and skills of the decision maker and the decision-making style that they use. Perhaps the findings of such research would make it possible to construct 
a hierarchy of the features proposed in the literature and could have an impact on managerial practice by encouraging decision-makers to develop and hone those abilities and skills that are of key importance to their specific decisionmaking style.

\section{Summary}

The profile of an intuitive decision maker and the use of intuition in decision-making practice

The aim of this paper is to determine the relationship between the personality traits identified in the literature as characteristic of an intuitive decision-maker and the use of intuition in the decisionmaking process. In order to empirically verify this issue, the author conducted a pilot study.

The article consists of three principal parts and is both theoretical and empirical in nature. The first part presents the essence of intuition and attempts to define this ambiguous concept. Next, the personality traits, abilities and predispositions which make up the profile of an intuitive decision maker are discussed. The final part of the paper is devoted to presenting the results obtained in the course of this empirical research.

Keywords: intuition, decision-making, decision-maker profile.

\section{Streszczenie}

Profil intuicyjnego decydenta a wykorzystanie intuicji w praktyce podejmowania decyzji

Celem artykułu jest zidentyfikowanie zależności między cechami osobowości jednostki określanymi w literaturze przedmiotu jako charakterystyczne dla intuicyjnego decydenta a wykorzystaniem intuicji w procesach podejmowania decyzji. W celu empirycznej weryfikacji tego problemu autorka przeprowadziła badania empiryczne o charakterze pilotażowym.

Artykuł składa się z trzech zasadniczych części i ma charakter rozważań zarówno teoretycznych, jak i empirycznych. W pierwszej, zaprezentowano istotę intuicji podejmując jednocześnie próbę zdefiniowania tego niejednoznacznego pojęcia. Następnie przedstawiono cechy osobowości, zdolności i predyspozycje intuicyjnego decydenta składające się na jego profil. Końcowa część

Theory of Organization and Management 
artykułu poświęcona została prezentacji rezultatów poznawczych uzyskanych w toku zrealizowanych badań empirycznych.

\section{Słowa \\ kluczowe: intuicja, podejmowanie decyzji, profil intuicyjnego decydenta.}

JEL

Classification: M12

\section{References}

1. Agor W.H. (1998),Intuicja w organizacji. Jak twórczo przewodzić i zarządzać, Wydawnictwo Personalnej Szkoły Biznesu, Kraków.

2. Allinson, C.W., Hayes, J. (2003), Allinson-Hayes Cognitive Style Index, "Journal of Occupational and Organizational Psychology", (76).

3. Blume, B.D., Covin, J.G. (2011), Attributions to intuition in the venture Founding process: Do entrepreneurs actually use intuition Or Just say that they do?, "Journal of Business Venturing", 26.

4. Goldberg, P. (2000), The Role of Intuition in Strategic Decision Making, "Human Relations", January (53).

5. Harper S.C. (1998), Intuicja: Co odróżnia dyrektorów od kierowników niższych szczebli, W.H. Agor (red.), Intuicja w organizacji. Jak twórczo przewodzić iI zarządzać, Wydawnictwo Profesjonalnej Szkoły Biznesu, Kraków 1998.

6. Haensel, Heuch, Schweitzer (2002), Erfolgsfaktor Intuition. Geistesblitze in Organisationen, "Zeitschriftfür Organisationsentwicklung", No. 1.

7. Hogarth R.M. (2001), Educating intuition, University of Chicago Press.

8. Jung C.G. (1933), Psychological types, Harcourt, Brace, and Company, New York.

9. Kahneman D. (2003), A Perspective on Judgment and Choice, "American Psychologist" 58.

10. Kahneman, D., Klein, G. (2009), Conditions for intuitive expertise: a failure to disagree, "The American Psychologist", 64.

11. Klein G. (2003), Intuition at work: Why developing your gut instincts will make you better at what you do?, Currency, Doubleday, New York.

12. Laufer, H. (2008), Podejmowanie decyzji. Jak unikać ryzyka. Jak efektywnie dziatać, Wydawnictwo BC Edukacja, Warszawa.

13. Myers D.G. (2002), Intuition: Its Power and Perils, Yale University Press, New Haven.

14. Policastro E. (1999), Intuition, [in:] Runco M. A., Pritzker S. R. (eds.), Encyclopedia of Creativity, Vol. 2, Academic Press, San Diego.

15. Raidl M.H., Lubart T.I. (2000-2001), An Empirical Study of Intuition and Creativity, "Imagination, Cognition and Personality". 
16. Rowan, R. (1987), The Intuitive Manager, Berkley.

17. Sadler-Smith E. (2008), Inside intuition, Routledge, New York 2008.

18. Salas, E., Rosen, M.A., DiazGranados, D. (2010), Expertise-based intuition and decision making in organizations, "Journal of Management", 36.

19. Serafin K. (2006), Intuicja jako czynnik wspóttworzacy sukces menedżera, Studia Ekonomiczne, No. 37, Zarządzanie strategiczne w przedsiębiorstwie, Wydawnictwo Akademii Ekonomicznej w Katowicach.

20. Simon H. (1987), Making Management Decisions: The Role of Intuition and Emotions, "Academy of Management Executives", February.

21. Stańczyk S., Sus A. (2013), Intuicja w zarządzaniu, Zeszyty Naukowe Politechniki Łódzkiej, Organizacja i Zarządzanie, No. 1147, Issue. 52.

22. Szerzyńska J. (2009), Jezzyk intuicji. Rola języka w procesach pamięciowych i intuicyjnych, "Rocznik Kognitywistyczny", Vol. 3.

23. Tokarski S. (2001),Intuicyjne podejmowanie decyzji w organizacjach o różnej formie własności, Prace Naukowe Akademii Ekonomiczne we Wrocławiu, No. 900, Wydawnictwo Akademii Ekonomicznej we Wrocławiu, Wrocław.

24. Westcott M.R., Ranzoni J.H. (1963), Correlates of Intuitive Thinking, "Psychological Reports", No. 12.

25. Woiceshyn J. (2009), Lessons from "Good Minds": How CEOs Use Intuition, Analysis and Guiding Principles to Make Strategic Decisions, "Long Range Planning", 42, 2009. 